\title{
Natural interfaces in VR - comparative analysis
}

\section{Naturalne interfejsy w VR - analiza porównawcza}

\author{
Adrian Madoń ", Dawid Majdanik*, Tomasz Szymczyk \\ Department of Computer Science, Lublin University of Technology, Nadbystrzycka 36B, 20-618 Lublin, Poland
}

\begin{abstract}
The article presents the results of a comparative analysis of contemporary virtual reality devices. The analysis focuses on both the analysis of technical parameters of the goggles as well as comparison of natural interfaces. The following devices were tested: HTC Vive, Oculus Rift, PlayStation VR, Samsung Gear VR. The most ergonomic and userfriendly interface turned out to be Oculus Rift, while goggles Samsung Gear VR were the worst from tested devices.
\end{abstract}

Keywords: natural interfaces; virtual reality; comparative analysis

\section{Streszczenie}

W artykule zaprezentowano wyniki analizy porównawczej współczesnych urządzeń umożliwiających projekcję wirtualnego środowiska. Analiza dotyczyła zarówno analizy parametrów technicznych samych gogli jak również porównania ergonomii interfejsów. Przetestowano następujące urządzenia: HTC Vive, Oculus Rift, PlayStation VR, Samsung Gear VR. Najbardziej ergonomicznym i przyjaznym użytkownikowi interfejsem okazał się Oculus Rift, natomiast najgorzej w teście wypadły gogle Samsung Gear VR.

Słowa kluczowe: naturalne interfejsy; wirtualna rzeczywistość; analiza porównawcza

${ }^{*}$ Corresponding authors

Email address*: adrian.madon@pollub.edu.pl (A. Madoń), dawid.majdanik@pollub.edu.pl (D. Majdanik)

CPublished under Creative Common License (CC BY-SA v4.0)

\section{Wstęp}

Wirtualna rzeczywistość (ang. Virtual Reality) to nowa i rozwijająca się technologia [1]. Jej założeniem jest imitacja wirtualnego świata i jego elementów w taki sposób, by osoba korzystająca $\mathrm{z}$ tej technologii mogła poczuć się jakby rzeczywiście była w tym wirtualnym miejscu [2]. Stopień w jakim użytkownik odbiera VR nazywany jest immersją [3]. Korzystanie z wirtualnej rzeczywistości dąży do uzyskania jak największego stopnia immersji.

Popularność oraz szybki rozwój przyczynia się do ogromnej sprzedaży urządzeń obsługujących VR [4]. Wirtualna rzeczywistość otwiera przed ludźmi nowe możliwości, nowe problemy oraz nowe rozwiązania. Technologia ta swoją popularność zawdzięcza wielu aspektom. Jednym z powodów takiej popularności jest powszechny dostęp do aplikacji oraz urządzeń, które obsługują wirtualną rzeczywistość. Kolejnym aspektem jest udostępniane API producentów urządzeń VR, co pomaga $\mathrm{w}$ rozpowszechnianiu $\mathrm{i}$ tworzeniu aplikacji nawet bez dużej wiedzy programistycznej. Wirtualna rzeczywistość swoje zastosowanie znajduje nie tylko w gałęzi rozrywki pod postacią gier i programów, ale także szeroko wykorzystywana jest do symulacji i nauczania ludzi w medycynie [5] oraz wojsku [6]. Tak duży zakres zastosowań przekłada się na ogromną i wciąż rosnącą liczbę użytkowników, co z kolei przekłada się na potrzebę przystosowania oraz ułatwienia korzystania $\mathrm{z}$ tej technologii a także ciągłe poprawki i udogodnienia.

\section{Współczesne interfejsy użytkownika}

Aplikacja oraz użytkownik wymieniają między sobą informacje za pomocą interfejsów. Interfejsy można podzielić na tekstowe, graficzne oraz naturalne [7].

Przedstawicielem interfejsu tekstowego jest CLI (ang. Command Line Interface), czyli wiersz poleceń jest to najprostszy interfejs tekstowy, w którym użytkownik wysyła sygnały do programu za pomocą klawiatury czy też specjalnych skryptów. Jest to jeden z pierwszych interfejsów, które pojawiły się w codziennym użytku. Można je spotkać do tej pory, na przykład w konsoli systemu Windows lub Linux [8].

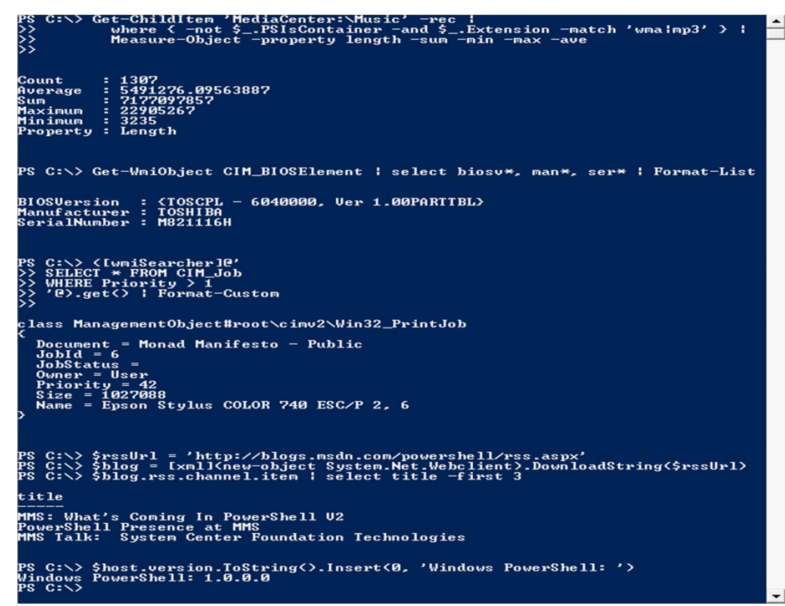

Rysunek 1: Rysunek Powershell systemu Windows [8].

GUI (ang. Graphical User Interface), czyli interfejs graficzny, w którym użytkownik komunikuje się z programem za pomocą myszki lub dotyku. Jest to obecnie 
jeden z najbardziej popularnych interfejsów. Używane one są w najpopularniejszych systemach operacyjnych Windows oraz na większości urządzeń przenośnych korzystających z systemów Android lub iOS [8].

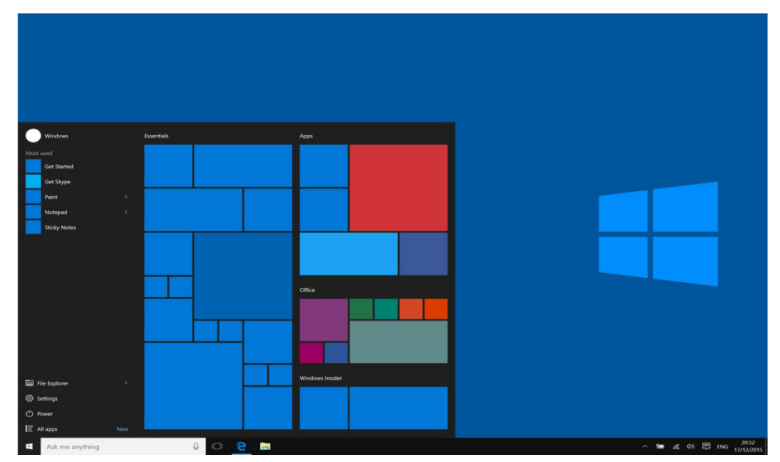

Rysunek 2: Szkielet menu w systemie Windows 10 [8].

NUI (ang. Natural User Interface), czyli interfejs naturalny, w którym użytkownik porozumiewa się z programem za pomocą naturalnych poleceń, takich jak ruch ręką, ruch głową czy też ruch ciała. Najczęściej spotykanym interfejsem naturalnym jest GUI smartfonów czy też innych urządzeń $\mathrm{z}$ ekranem dotykowym [9].

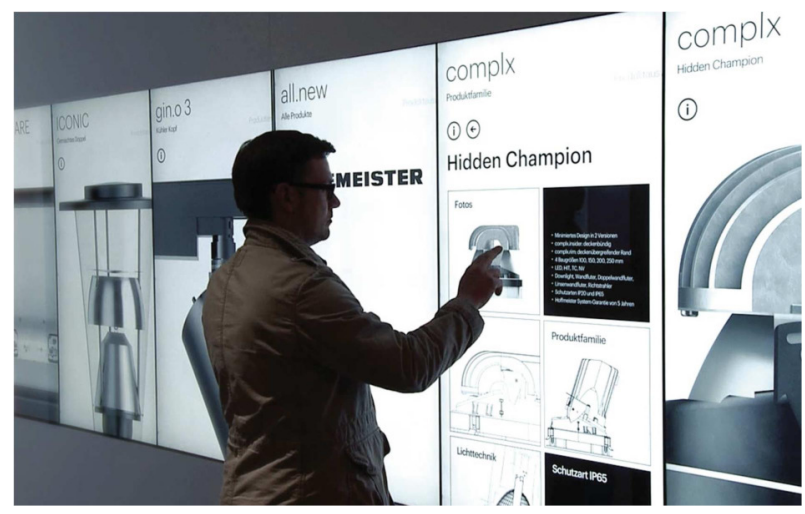

Rysunek 3: Naturalny interfejs graficzny [9].

\section{3. Środowisko testowe}

Analiza porównawcza zarówno interfejsów jak i sprzętu została wykonana na następujących urządzeniach:

- HTC Vive,

- Oculus Rift,

- PlayStation VR,

- Samsung Gear VR.

W zakresie analizy porównawczej parametrów technicznej porównane zostały takie czynniki jak: waga gogli, ich cena $\mathrm{w}$ dniu premiery oraz generowana przez nie grafika. W zakresie analizy interfejsów porównane zostały takie czynniki jak: intuicyjność interfejsu głównego, standardowo dołączone kontrolery, dostępne dodatkowe urządzenia peryferyjne oraz występujące w nich interfejsy naturalne.

HTC Vive są to gogle stworzone przy współpracy firm HTC oraz Valve. Pierwszy model urządzenia HTC Vive został wydany na rynku światowym na początku kwietnia 2016 roku. Gogle te stosują innowacyjną technologię śledzenia ruchów głowy użytkownika i kontro- lerów o nazwie „room scale”. Polega ona na wykorzystaniu dwóch stacji bazowych, które tworzą $360^{\circ}$ wirtualną przestrzeń, a następnie emitują światła podczerwieni do kontrolera i gogli w celu wykrycia aktualnej pozycji użytkownika.

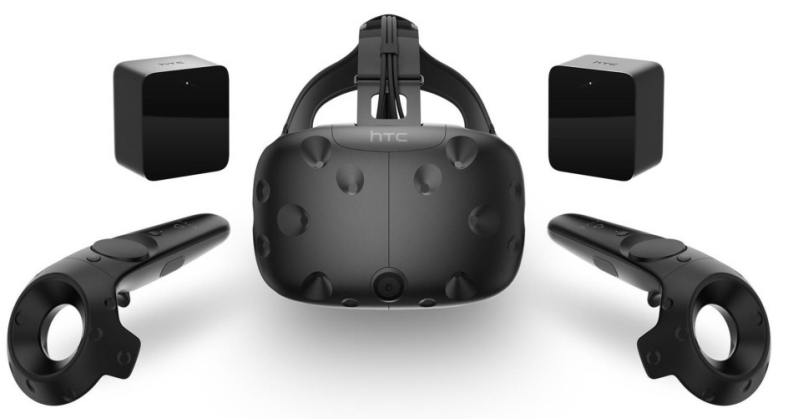

Rysunek 4: Gogle HTC Vive z kontrolerami oraz dwiema stacjami bazowymi [10].

Poniższa tabela 1 przedstawia główne parametry techniczne występujące w poszczególnych wersjach gogli HTC Vive.

Tabela 1: Porównanie parametrów technicznych HTC Vive, HTC Vive Cosmos, HTC Vive Pro.

\begin{tabular}{|c|c|c|c|}
\hline & HTC Vive & $\begin{array}{c}\text { HTC Vive } \\
\text { Cosmos }\end{array}$ & HTC Vive Pro \\
\hline Typ Ekranu & $\begin{array}{l}\text { Podwójny } \\
\text { AMOLED } \\
3.6 \text { cala }\end{array}$ & $\begin{array}{c}\text { Podwójny } 3.4 \\
\text { cala }\end{array}$ & $\begin{array}{c}\text { Podwójny } \\
\text { AMOLED } 3.5 \\
\text { cala }\end{array}$ \\
\hline $\begin{array}{l}\text { Rozdzielczość } \\
{[\mathrm{px}]}\end{array}$ & $2160 \times 1200$ & $2880 \times 1700$ & $2880 \times 1600$ \\
\hline $\begin{array}{c}\text { Częstotliwość } \\
\text { odświeżania } \\
{[\mathrm{Hz}]}\end{array}$ & 90 & 90 & 90 \\
\hline $\begin{array}{c}\text { Pole widzenia } \\
{\left[{ }^{\circ}\right]}\end{array}$ & 110 & 110 & 110 \\
\hline Sensory & $\begin{array}{c}\text { SteamVR } \\
\text { tracking, } \\
\text { G-Sensor, } \\
\text { żyroskop, } \\
\text { czujnik } \\
\text { zbliżeniowy }\end{array}$ & $\begin{array}{c}\text { G-Sensor, } \\
\text { żyroskop, } \\
\text { ustawienia } \\
\text { komfortu oczu } \\
\text { (IPD) }\end{array}$ & $\begin{array}{c}\text { SteamVR } \\
\text { tracking, } \\
\text { G-Sensor, } \\
\text { żyroskop, } \\
\text { czujnik zbliże- } \\
\text { niowy, usta- } \\
\text { wienia komfor- } \\
\text { tu oczu (IPD) }\end{array}$ \\
\hline Ergonomia & $\begin{array}{c}\text { Regulacja } \\
\text { rozstawu } \\
\text { okularów } \\
\text { i soczewki }\end{array}$ & $\begin{array}{l}\text { Regulacja } \\
\text { rozstawu } \\
\text { okularów } \\
\text { i soczewki, } \\
\text { odchylany } \\
\text { daszek, regu- } \\
\text { lowane usta- } \\
\text { wienia kom- } \\
\text { fortu oczu } \\
\text { (IPD) }\end{array}$ & $\begin{array}{c}\text { Regulacja } \\
\text { rozstawu okula- } \\
\text { rów } \\
\text { i soczewki, } \\
\text { odchylany } \\
\text { daszek, regulo- } \\
\text { wane ustawie- } \\
\text { nia komfortu } \\
\text { oczu (IPD) }\end{array}$ \\
\hline
\end{tabular}

Oculus Rift to gogle mające swoje początki na crowdfundingowym serwisie - Kickstarter, na której uzbierało niemalże $2.5 \mathrm{mln}$ dolarów. Gogle te do śledzenia pozycji gogli jak i kontrolerów wykorzystuje system o nazwie „Oculus Insight”. Polega on na przewidzeniu trajektorii ruchów Oculus Rift za pomocą pięciu kamer zamieszczonych na goglach oraz światła podczerwieni LED na kontrolerach. 


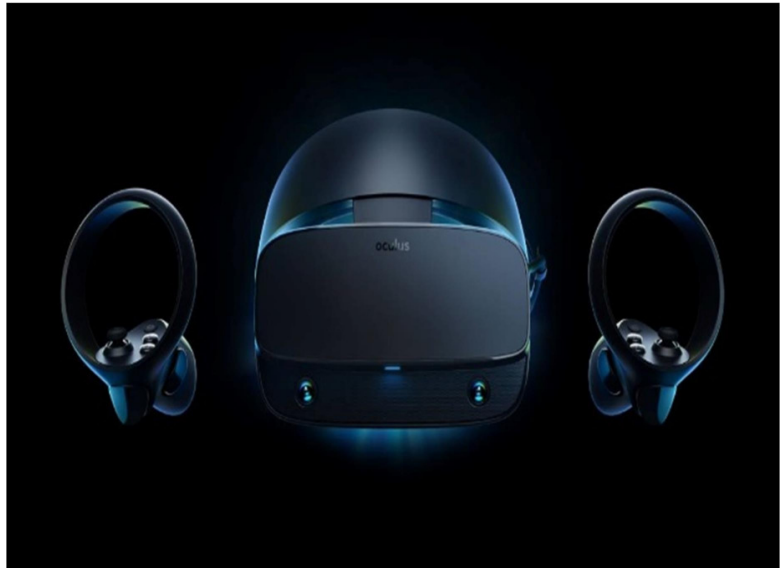

Rysunek 5: Gogle Oculus Rift z kontrolerami [11].

Poniższa tabela przedstawia główne parametry techniczne występujące w poszczególnych wersjach gogli Oculus.

Tabela 2: Porównanie parametrów technicznych Oculus Rift, Oculus Rift S, Oculus Quest, Oculus Go.

\begin{tabular}{|c|c|c|c|}
\hline & Oculus Rift & Oculus Rift S & $\begin{array}{c}\text { Oculus } \\
\text { Quest }\end{array}$ \\
\hline Rodzaj zestawu & $\begin{array}{c}\text { wymaga } \\
\text { komputera }\end{array}$ & $\begin{array}{c}\text { wymaga } \\
\text { komputera }\end{array}$ & All in one \\
\hline Typ Ekranu & $\begin{array}{c}\text { Podwójny } \\
\text { OLED }\end{array}$ & $\begin{array}{c}\text { Pojedynczy } \\
\text { LCD }\end{array}$ & $\begin{array}{c}\text { Podwójny } \\
\text { OLED }\end{array}$ \\
\hline $\begin{array}{c}\text { Rozdzielczość } \\
{[\mathrm{px}]}\end{array}$ & $\begin{array}{c}2160 \mathrm{x} \\
1200\end{array}$ & $\begin{array}{c}2560 \mathrm{x} \\
1440\end{array}$ & $\begin{array}{c}2880 \mathrm{x} \\
1600\end{array}$ \\
\hline $\begin{array}{c}\text { Częstotliwość } \\
\text { odświeżania [Hz] }\end{array}$ & 90 & 80 & 72 \\
\hline $\begin{array}{c}\text { Regulacja dystansu } \\
\text { soczewek }\end{array}$ & Tak & Nie & Tak \\
\hline
\end{tabular}

PlayStation VR to gogle VR stworzone przez firmę Sony wykorzystujące konsolę PS4 do generowania grafiki. Do śledzenia trajektorii ruchów użytkownika służy specjalna kamera do PS4, która śledzi emitowane niebieskie światło LED przez gogle oraz ruchy w kontrolerach.

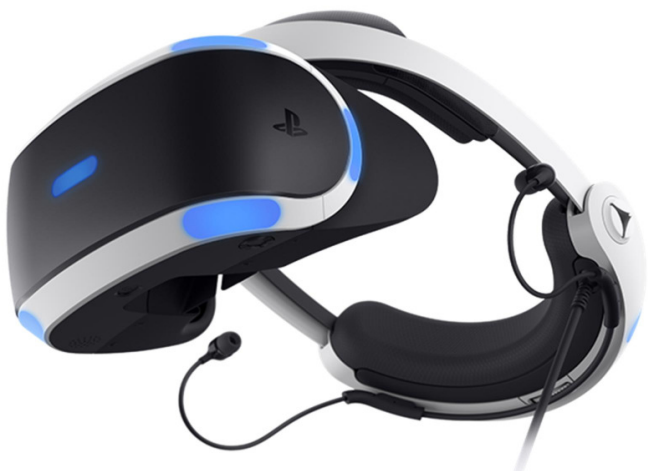

Rysunek 6: Gogle PlayStation VR [12].

Poniższa tabela przedstawia główne parametry techniczne gogli PlayStation VR.

Gogle Samsung Gear VR zostały zaprojektowane przez Samsung Electronics z pomocą Oculus VR. Urządzenie to współpracuje jedynie z telefonami Samsunga, zaczynając od Galaxy S6, a kończąc na najnowszych Galaxy S10+ i Note 9.
Tabela 3: Opis parametrów technicznych gogli PlayStation VR.

\begin{tabular}{|c|c|}
\hline Typ Ekranu & Pojedynczy 5.7 cala \\
\hline $\begin{array}{c}\text { Rozdzielczość } \\
{[\mathrm{px}]}\end{array}$ & $\begin{array}{c}\text { 1920x1080 pełny kolor OLED RGB } \\
(1920 \times R \text { GBx1080) }\end{array}$ \\
\hline $\begin{array}{c}\text { Częstotliwość odświeża- } \\
\text { nia [Hz] }\end{array}$ & 90 lub 120 \\
(w zależności od aplikacji)
\end{tabular}

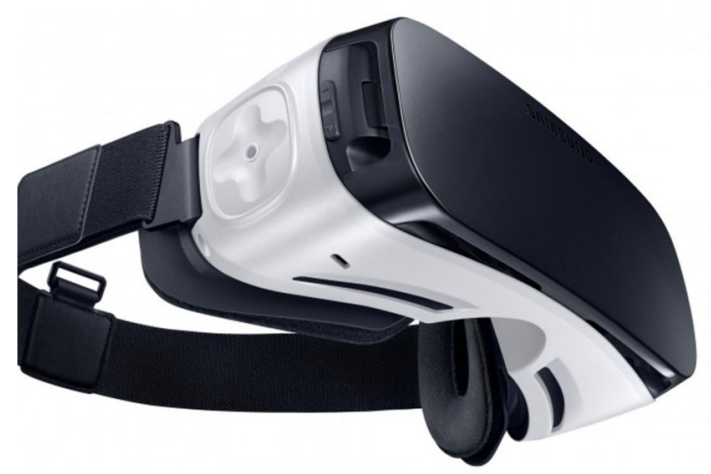

Rysunek 7: Gogle Samsung Gear VR [13].

Poniższa tabela przedstawia główne parametry techniczne gogli Samsung Gear VR.

Tabela 4: Opis parametrów technicznych gogli Samsung Gear VR.

\begin{tabular}{|c|c|}
\hline Typ Ekranu & Brak - ekranem jest telefon komórkowy \\
\hline $\begin{array}{c}\text { Rozdzielczość } \\
{[\mathrm{px}]}\end{array}$ & Taka sama jak telefonu \\
\hline $\begin{array}{c}\text { Częstotliwość odświeżania } \\
{[\mathrm{Hz}]}\end{array}$ & Taka sama jak telefonu \\
\hline $\begin{array}{c}\text { Pole widzenia } \\
{\left[{ }^{\circ}\right]}\end{array}$ & 101 (w przypadku starszych modeli 96$)$ \\
\hline
\end{tabular}

\section{Analiza porównawcza}

Celem analizy porównawczej jest zdefiniowanie, które urządzenie posiada najlepsze parametry techniczne oraz najbardziej naturalny interfejs.

\subsection{Kryteria analizy}

Analiza podzielona jest na dwie części, pierwsza porównuje parametry techniczne urządzeń, druga natomiast skupia się na porównaniu interfejsów naturalnych. Obie analizy dokładnie opisują poszczególne cechy w skali od 0 do 5, gdzie:

- 0 oznacza brak możliwości ocenienia lub brak cechy,

- 1 oznacza nieakceptowalną cechę,

- 2 oznacza słabą akceptowalność,

- 3 oznacza dostatecznie akceptowalną cechę,

- 4 oznacza dobrą akceptowalność,

- 5 oznacza najlepszą akceptowalność.

W ogólnym zestawieniu umożliwi to na podsumowanie oraz ułożenie w kolejności wyników, które otrzymano analizując wybrane urządzenia, co z kolei pozwoli na wybranie najlepszego urządzenia pod względem technicznym, pod względem naturalnych interfejsów oraz najlepszego urządzenia łącznie. 


\subsection{Analiza parametrów technicznych}

Poniższy rozdział zawiera szczegółową analizę parametrów technicznych poszczególnych urządzeń VR. Do analizy zostały wybrane następujące aspekty gogli:

- waga gogli,

- cena w dniu premiery,

- grafika.

Do oceny analizy wagi urządzeń VR zostało wykorzystane badanie LeClair [14] mówiące, że czym mniejsza waga gogli tym większe subiektywne uczucie komfortu u użytkowników. Najwyższą ocenę (5) otrzymały gogle posiadającą wagę poniżej $500 \mathrm{~g}$ a każde kolejne $100 \mathrm{~g}$ powyżej $500 \mathrm{~g}$ powoduje spadek oceny o 1 .

Wprowadzone kryterium punktowe zostało ustalone empirycznie na podstawie odczucia użytkownika. Ciężkie gogle są nieprzyjemne w obcowaniu. Wspomniane $100 \mathrm{~g}$ to zauważalna i odczuwalna waga.

Tabela 5: Oceniona analiza wagi poszczególnych zestawów VR.

\begin{tabular}{|c|c|c|}
\hline Nazwa gogli & Waga [g] & Ocena \\
\hline $\begin{array}{c}\text { Samsung Gear VR } \\
\text { bez telefonu }\end{array}$ & 345 & 5 \\
\hline Oculus Go & 468 & 5 \\
\hline Oculus Rift & 470 & 5 \\
\hline HTC Vive & 470 & 5 \\
\hline Oculus Rift S & 510 & 4 \\
\hline Oculus Quest & 571 & 4 \\
\hline PlayStation VR & 610 & 3 \\
\hline HTC Vive Cosmos & 645 & 3 \\
\hline HTC Vive Pro & 803 & 1 \\
\hline
\end{tabular}

Kolejnym kryterium analizy technicznej urządzeń VR była ich cena w dniu premiery. Wszelkie nowoczesne gogle VR są bardzo kosztowne. Wynika to $\mathrm{z}$ tego, że te urządzenia zazwyczaj potrzebują wyświetlacza o wysokiej rozdzielczości, wielu czujników ruchu gogli oraz na kontrolerach i urządzenia do generowania grafiki (konsola, komputer stacjonarny lub telefon).

Cena produktu dla przeciętnych klientów jest zazwyczaj jednym z głównych wyznacznikiem zakupu produktu, więc najwyższą ocenę otrzymały urządzenia najtańsze w dniu premiery.

Tabela 6: Oceniona analiza ceny w dniu premiery poszczególnych zestawów VR.

\begin{tabular}{|c|c|c|}
\hline Nazwa gogli & Cena [\$] & Ocena \\
\hline Samsung Gear VR & 99.99 & 5 \\
\hline Oculus Go & 199 & 5 \\
\hline Oculus Quest & 399 & 4 \\
\hline PlayStation VR & 399 & 4 \\
\hline Oculus Rift S & 399 & 4 \\
\hline HTC Vive & 599 & 3 \\
\hline Oculus Rift & 599.99 & 3 \\
\hline HTC Vive Pro & 799 & 2 \\
\hline HTC Vive Cosmos & 900 & 1 \\
\hline
\end{tabular}

Ostatnim kryterium analizy technicznej urządzeń VR była grafika. Analizę grafiki przeprowadzonej dwoma sposobami. Pierwszym sposobem było zauważenie różnic w generowanej grafice pomiędzy poszczególnymi goglami VR, natomiast drugą metodą było badanie występowania efektu „screen-door”, który polega na pojawianiu się czarnych artefaktów przy dużym przybliżeniu obrazu (Rys. 8 i Rys. 9). a)

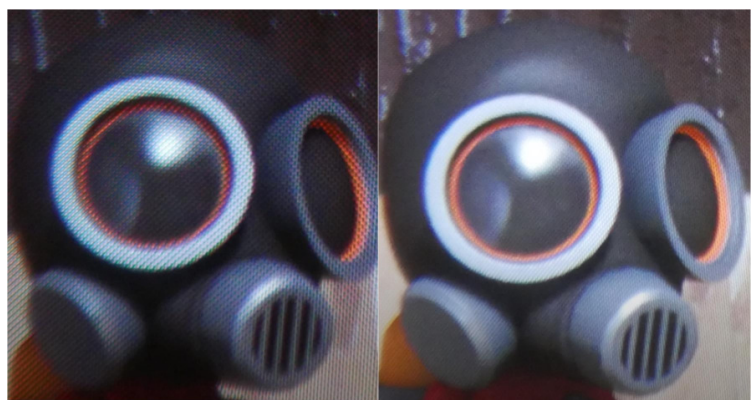

Rysunek 8: Porównanie modelu z soczewek gogli VR a) HTC Vive b) HTC Vive Pro [15].

a)

b)

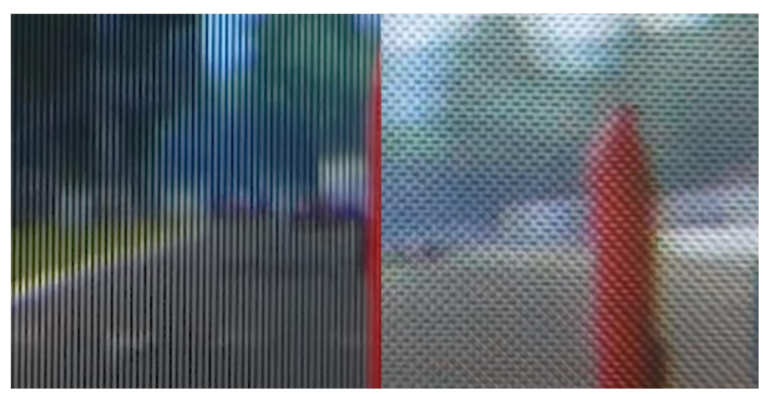

Rysunek 9: Porównanie „screen-door effect” dla urządzeń VR a) Oculus Rift S b) HTC Vive Pro [16].

Poniższa tabela zawiera ocenioną analizę grafiki badanych urządzeń VR.

Tabela 7: Oceniona analiza grafiki poszczególnych zestawów VR.

\begin{tabular}{|c|c|}
\hline Nazwa gogli & Ocena grafiki \\
\hline Oculus Rift S & 5 \\
\hline HTC Vive Pro & 4 \\
\hline HTC Vive Cosmos & 4 \\
\hline PlayStation VR & 3 \\
\hline Oculus Quest & 3 \\
\hline Oculus Rift & 3 \\
\hline HTC Vive & 2 \\
\hline Oculus Go & 1 \\
\hline Samsung Gear VR & 1 \\
\hline
\end{tabular}

\subsection{Analiza interfejsów naturalnych}

Poniższy rozdział zawiera analizę zdefiniowanych na podstawie materiałów parametrów poszczególnych urządzeń VR. Do analizy zdefiniowano następujące kategorie:

- menu główne,

- dodatkowe urządzenie peryferyjne - rękawice,

- standardowe urządzenie peryferyjne - kontrolery,

- wykrywanie naturalnych ruchów.

Pierwszym urządzeniem poddanym analizie jest HTC Vive. Menu główne zaimplementowane w urządzeniu HTC Vive posiada wiele udogodnień związanych z jego obsługą, posiada zaimplementowane wykrywanie wielu naturalnych ruchów oraz dba o odczucia wizualne i dźwiękowe użytkownika. Standardowy kontroler dołączony do urządzenia posiada rozstawione przyciski w taki sposób, że ręka układa się w naturalnej pozycji, nie jest on za ciężki co powoduje, że jego używanie jest bardzo przyjemnie i nie męczy dłoni. Do 
HTC Vive dostępne jest wiele urządzeń peryferyjnych, które można podłączyć bez żadnych problemów, ponieważ posiada on wbudowaną obsługę urządzeń trzecich. Ocena wyżej opisanych parametrów przedstawiona jest w tabeli 8 .

Tabela 8: Tabela przedstawiająca ocenę poszczególnych elementów analizy HTC Vive.

\begin{tabular}{|c|c|}
\hline Element analizy & Ocena \\
\hline Menu główne & 5 \\
\hline $\begin{array}{c}\text { Dodatkowe urządzenie peryfe- } \\
\text { ryjne - rękawice }\end{array}$ & 5 \\
\hline $\begin{array}{c}\text { Standardowe urządzenie peryfe- } \\
\text { ryjne - kontrolery }\end{array}$ & 5 \\
\hline $\begin{array}{c}\text { Wykrywanie naturalnych ru- } \\
\text { chów }\end{array}$ & 5 \\
\hline
\end{tabular}

Kolejne urządzenie poddane analizie to Oculus Rift. Główny interfejs graficzny tego urządzenia, podobnie jak HTC Vive, posiada zaimplementowane wiele udogodnień, porusza zmysł wzroku oraz słuchu i obsługuje wiele ruchów naturalnych. Standardowy kontroler dołączony do urządzenia jest wygodny w użytkowaniu, jednak rozstaw jego przycisków powoduje, że ręka nie do końca układa się w naturalnej pozycji, co przy dłuższym użytkowaniu powoduje zmęczenie dłoni. Dodatkowe urządzenia peryferyjne są obsługiwane przez te okulary, jednak nie wszystkie modele można z nimi połączyć, niektóre modele nie są przystosowane do współpracy z Oculus Rift. Ocena wyżej opisanych parametrów przedstawiona jest $\mathrm{w}$ tabeli 9 .

Tabela 9: Tabela przedstawiająca ocenę poszczególnych elementów analizy Oculus Rift.

\begin{tabular}{|c|c|}
\hline Element analizy & Ocena \\
\hline Menu główne & 5 \\
\hline $\begin{array}{c}\text { Dodatkowe urządzenie peryfe- } \\
\text { ryjne - rękawice }\end{array}$ & 4 \\
\hline $\begin{array}{c}\text { Standardowe urządzenie peryfe- } \\
\text { ryjne - kontrolery }\end{array}$ & 4 \\
\hline $\begin{array}{c}\text { Wykrywanie naturalnych ru- } \\
\text { chów }\end{array}$ & 5 \\
\hline
\end{tabular}

Następne testowane urządzenie to PlayStation VR. Jego interfejs to przekonwertowany standardowy interfejs PlayStation w wersji wirtualnej, co przekłada się na gorsze odczucie podczas korzystania w wirtualnej rzeczywistości. Pomimo tej konwersji, PlayStation VR zawiera zaprogramowane naturalne ruchy oraz ich wykrywanie. Urządzenie to nie posiada możliwości podłączenia urządzeń peryferyjnych w postaci rękawic, co bardzo źle wpływa na ocenę w tym zakresie. Standardowe kontrolery PlayStation VR są wygodne, mają odpowiednio rozstawione przyciski, lecz muszą być one widoczne przez kamerę PlayStation Eye, co w niektórych momentach ogranicza rozgrywkę, na przykład gdy gracz stoi tyłem do kamery i swoim ciałem zasłania kontrolery. Ocena wyżej opisanych parametrów przedstawiona jest w tabeli 10.

Samsung Gear VR to ostatni $\mathrm{z}$ testowanych urządzeń. Interfejs graficzny tego urządzenia, podobnie jak w przypadku wcześniej analizowanych urządzeń, posiada zaprogramowane wykrywanie naturalnych ruchów oraz dodatki dźwiękowe i wizualne pomagające w sprawny sposób zarządzać interfejsem. Samsung
Gear VR nie posiada możliwości podłączenia dodatkowych urządzeń innych niż standardowy pad, co skutkuje brakiem oceny tego elementu analizy. Standardowy kontroler dołączony do urządzenia jest mały, ułożenie jego przycisków pozostawia wiele możliwości do poprawy, lecz pomimo tych wad nie jest on uciążliwy w używaniu. Ocena wyżej opisanych parametrów przedstawiona jest $\mathrm{w}$ tabeli 11 .

Tabela 10: Tabela przedstawiająca ocenę poszczególnych elementów analizy PlayStation VR.

\begin{tabular}{|c|c|}
\hline Element analizy & Ocena \\
\hline Menu główne & 4 \\
\hline $\begin{array}{c}\text { Dodatkowe urządzenie peryfe- } \\
\text { ryjne - rękawice }\end{array}$ & 0 \\
\hline $\begin{array}{c}\text { Standardowe urządzenie peryfe- } \\
\text { ryjne - kontrolery }\end{array}$ & 4 \\
\hline $\begin{array}{c}\text { Wykrywanie naturalnych ru- } \\
\text { chów }\end{array}$ & 4 \\
\hline
\end{tabular}

Tabela 11: Tabela przedstawiająca ocenę poszczególnych elementów analizy Samsung Gear VR.

\begin{tabular}{|c|c|}
\hline Element analizy & Ocena \\
\hline Menu główne & 4 \\
\hline $\begin{array}{c}\text { Dodatkowe urządzenie peryfe- } \\
\text { ryjne - rękawice }\end{array}$ & 0 \\
\hline $\begin{array}{c}\text { Standardowe urządzenie peryfe- } \\
\text { ryjne - kontrolery }\end{array}$ & 3 \\
\hline $\begin{array}{c}\text { Wykrywanie naturalnych ru- } \\
\text { chów }\end{array}$ & 4 \\
\hline
\end{tabular}

\section{Wnioski}

Analiza porównawcza wyżej wymienionych urządzeń pozwoliła na wybranie najbardziej optymalnego urządzenia pod względem zarówno technicznym jak i ergonomicznym oraz pozwoliło na zdefiniowanie które z nich posiada najlepszy według założonych kryteriów interfejs naturalny.

Tabela 12 przedstawia zbiorcze zestawienie ocen parametrów analizy porównawczej parametrów techniczną badanych urządzeń. Na podstawie tej tabeli można wywnioskować, że podczas analizy, najlepszy interfejs posiada urządzenie Oculus Rift S z wynikiem 14 punktów na 15 możliwych co stanowi 93\% wszystkich możliwych do zdobycia punktów, natomiast najgorsze parametry techniczne ma HTC Vive Pro, które uzyskało zaledwie 7 punktów.

Tabela 12: Tabela przedstawiająca sumę zdobytych punktów podczas analizy technicznej gogli VR.

\begin{tabular}{|c|c|c|c|c|}
\hline $\begin{array}{c}\text { Nazwa po- } \\
\text { szczególnych } \\
\text { urządzeń VR }\end{array}$ & $\begin{array}{c}\text { Waga } \\
\text { gogli VR }\end{array}$ & $\begin{array}{c}\text { Cena w } \\
\text { dniu } \\
\text { premiery } \\
\text { gogli VR }\end{array}$ & $\begin{array}{c}\text { Grafika } \\
\text { w gogli } \\
\text { VR }\end{array}$ & $\begin{array}{c}\text { Suma } \\
\text { punktów }\end{array}$ \\
\hline Oculus Rift S & 5 & 4 & 5 & 14 \\
\hline Oculus Quest & 4 & 4 & 3 & 11 \\
\hline Oculus Go & 5 & 5 & 1 & 11 \\
\hline Oculus Rift & 5 & 3 & 3 & 11 \\
\hline $\begin{array}{c}\text { Samsung Gear } \\
\text { VR }\end{array}$ & 4 & 5 & 1 & 10 \\
\hline HTC Vive & 5 & 3 & 2 & 10 \\
\hline PlayStation VR & 3 & 4 & 3 & 10 \\
\hline $\begin{array}{c}\text { HTC Vive } \\
\text { Cosmos }\end{array}$ & 3 & 1 & 4 & 8 \\
\hline HTC Vive Pro & 1 & 2 & 4 & 7 \\
\hline
\end{tabular}


Tabela 13 przedstawia zbiorcze zestawienie ocen parametrów analizy porównawczej interfejsów naturalnych ocenianych urządzeń. $\mathrm{Na}$ podstawie tej tabeli można wywnioskować, że podczas analizy naturalnych interfejsów urządzeń, najlepszy interfejs posiada urządzenie HTC Vive z wynikiem 18 punktów na 20 możliwych, natomiast najgorszy interfejs naturalny można spotkać w urządzeniu Samsung Gear VR, które uzyskało zaledwie 7 punktów.

Tabela 13: Tabela przedstawiająca sumy ocen poszczególnych elementów analizy interfejsów naturalnych wszystkich badanych urządzeń.

\begin{tabular}{|c|c|c|c|c|}
\hline $\begin{array}{c}\text { Element } \\
\text { analizy }\end{array}$ & $\begin{array}{c}\text { Liczba } \\
\text { punktów } \\
\text { zdobyta } \\
\text { przez } \\
\text { gogle } \\
\text { HTC } \\
\text { Vive }\end{array}$ & $\begin{array}{c}\text { Liczba } \\
\text { punktów } \\
\text { zdobyta } \\
\text { przez } \\
\text { gogle } \\
\text { Oculus } \\
\text { Rift }\end{array}$ & $\begin{array}{c}\text { Liczba } \\
\text { punktów } \\
\text { zdobyta } \\
\text { przez } \\
\text { gogle } \\
\text { PlayStation } \\
\text { VR }\end{array}$ & $\begin{array}{c}\text { Liczba } \\
\text { punktów } \\
\text { zdobyta } \\
\text { przez } \\
\text { gogle } \\
\text { Samsung } \\
\text { Gear VR }\end{array}$ \\
\hline Menu główne & 5 & 5 & 4 & 4 \\
\hline $\begin{array}{c}\text { Dodatkowe } \\
\text { urządzenie } \\
\text { peryferyjne- } \\
\text { rękawice }\end{array}$ & 5 & 4 & 0 & 0 \\
\hline $\begin{array}{c}\text { Standardowe } \\
\text { urządzenie } \\
\text { peryferyjne - } \\
\text { kontrolery }\end{array}$ & 5 & 4 & 4 & 3 \\
\hline $\begin{array}{c}\text { Wykrywanie } \\
\text { naturalnych } \\
\text { ruchów }\end{array}$ & 5 & 5 & 4 & 4 \\
\hline Suma punktów & 20 & 18 & 12 & 11 \\
\hline
\end{tabular}

Rysunek 10 przedstawia średnią sumę analiz parametrów technicznych dla poszczególnych serii badanych urządzeń VR (Tabela 12) oraz interfejsów naturalnych. Na jego podstawie wywnioskować można, że najlepsze okazały się urządzenia z serii Oculus, które uzyskały łączną sumę 29.75 punktów na 35 możliwych, natomiast najgorszy wynik uzyskały okulary Samsung Gear VR, otrzymując 21 punktów.

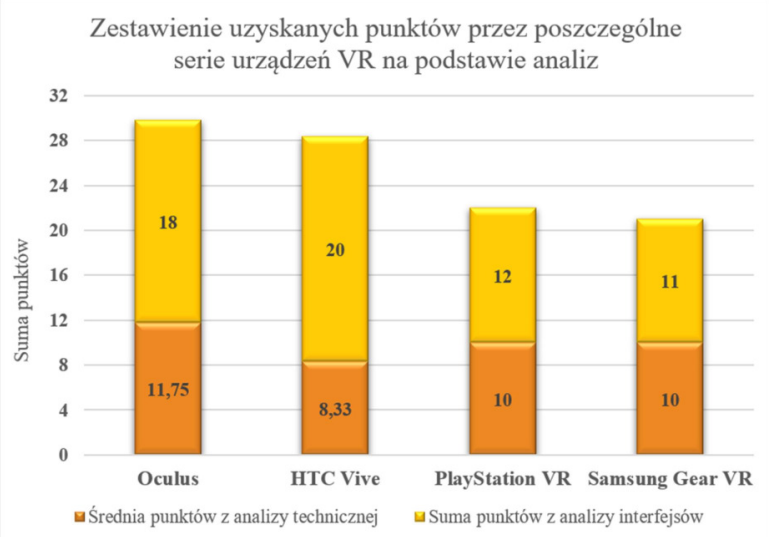

Rysunek 10: Wykres przedstawiający sumę punktów uzyskanych przez poszczególne serie badanych urządzeń VR.

Biorąc pod uwagę przeprowadzoną powyżej analizę wszelkich aspektów urządzeń wirtualnej rzeczywistości najlepszymi goglami okazały się Oculus Rift $\mathrm{S}$ ze względu na ich znakomite parametry techniczne jak i także zaimplementowane dla nich interfejsy naturalne.
Z wyników badań wywnioskować można, że nowsze modele osiągały lepsze wyniki niż ich poprzednicy, co spowodowane jest faktem, że wirtualna rzeczywistość jest nową i rozwijającą się technologią. Wywnioskować z tego można również to, że kolejne wersje urządzeń jak i nowe urządzenia będą miały coraz to lepsze osiągi pod względem parametrów jak i naturalności zaimplementowanych interfejsów.

Przeprowadzona analiza wybranych gogli pozwoliła wybrać najlepsze urządzenie pod względem technicznym, najlepsze urządzenie pod względem naturalności interfejsów oraz najlepsze urządzenie sumując uzyskane wyniki, co przełożyło się na osiągnięcie celu pracy.

\section{Literatura}

[1] S. M. LaValle, Virtual Reality, Cambridge University Press, 2019.

[2] M. Magnor, A. Sorkine-Hornung, Real VR - Immersive Digital Reality, Springer Nature 13 (2020) 301-306.

[3] Definicja immersji, https://pl.wikipedia.org/wiki/ Immersyjno\%C5\%9B\%C4\%87, [14.08.2020].

[4] Statystyki dotyczące liczby użytkowników VR i AR, https://www.emarketer.com/content/virtual-andaugmented-reality-users-2019 , [14.08.2020]

[5] R. Riener, M. Harders, Virtual Reality in Medicine, Springer Science \& Business Media, 2012.

[6] A. Lele, Virtual reality and its military utility, Institute for Defence Studies and Analyses 4(1) (2013) 17-26.

[7] Interfejsy graficzne, https://en.wikibooks.org/wiki/ A-level Computing/CIE/Computer systems, communications and software/System_software/ User interfaces, $[30.09 .2020]$.

[8] Interfejs użytkownika, https://pl.wikipedia.org/wiki/ Interfejs u\%C5\%BCytkownika, [30.09.2020].

[9] Naturalny interfejs użytkownika, https://tylersmcmillan. home.blog/2019/02/18/blog-6/, [30.09.2020].

[10] Debiut rynkowy HTC Vive https://www.theverge.com/ 2016/2/21/11081462/htc-vive-consumer-edition-pricerelease-date-mwc-2016, [30.10.2020]

[11] Opis parametrów technicznych urządzeń Oculus, http://oculus.com, [30.10.2020].

[12] Opis parametrów technicznych urządzeń PlayStation VR https://www.playstation.com/en-au/explore/playstationvr , [30.10.2020].

[13] Opis parametrów technicznych urządzeń Samsung Gear VR, https://www.roadtovr.com/samsung-gear-vr-2015model-now-60/, [30.10.2020].

[14] B. LeClair, P. O'Connor, S. Podrucky, W. B. Lievers, Measuring the mass and center of gravity of helmet systems for underground workers, International Journal of Industrial Ergonomics 64 (2018) 23-30.

[15] Przegląd i porównanie HTC Vive Pro, https://www. youtube.com/watch? $v=j m Z j J I y z-x A,[30.10 .2020]$.

[16] Porównanie Oculus RIFT S i HTC Vive Pro, www. youtube.com/watch?v=6N1Daam6izM , [30.10.2020]. 